\title{
POR UMA (PO)ÉTICA DA CONVIVÊNCIA: ANTOINE BERMAN, A AMÉRICA LATINA E A TRADUÇÃO EM MANIFESTO
}

\section{TOWARDS AN ETHICS AND A POETICS OF CONVIVIALITY: ANTOINE BERMAN, LATIN AMERICA AND THE} MANIFESTATION OF TRANSLATION

\section{Simone Christina Petry*}

\section{RESUMO}

Este ensaio visa apresentar aspectos relevantes do tempo que o tradutor francês e teórico da tradução Antoine Berman experimentou na América Latina (1970 a 1975, mais ou menos), especialmente no contexto da Argentina. Partindo disso, tentaremos demonstrar que essa experiência e a experiência de traduzir a literatura latino-americana, quando em diálogo com as reflexões de poetas e pensadores da primeira geração do romantismo alemão, o levarão à elaboração de uma ética da tradução, que, por sua vez, terá um impacto decisivo no modo como Berman entende a prática da tradução e as questões sócio-políticas e culturais que essa prática pode suscitar e provocar no contexto francês.

Palavras-chave: Antoine Berman; América Latina; ética da tradução.

\section{ABSTRACT}

This essay aims at presenting relevant aspects of the time the French translator and theoretician of translation Antoine Berman experienced in Latin America specially regarding the time he spent in Argentina (more or less from 1970 to 1975). Departing from this, we will try to demonstrate, that this experience and the experience of translating Latin American literature, when in dialogue with the reflections of poets and thinkers of the first generation of German Romanticism, will lead him to the elaboration of an ethics of translation, which, in turn, will decisively impact on the way Berman understands both the practice of translation and the socio-political and cultural issues that this practice can evoke and provoke in the French context.

Keywords: Antoine Berman; Latin America; ethics of translation.

Na década de 60, do séc. XX, a França enfrentou uma forte crise social e política que culminou com a greve geral marcada mundialmente como o acontecimento Maio

\footnotetext{
* Tradutora (A. Tabucchi, L. Pirandello, A. Berman). Doutora em Teoria e História Literária pela Unicamp. petry.simone@gmail.com
} 
de $68^{1}$. Esse movimento teve início com estudantes universitários que pleiteavam uma reforma educacional, mas muito rapidamente uniram-se a ele outras causas sociais como, por exemplo, a dos trabalhadores. Ideologias socialistas ganhavam força, naquele contexto, ao apoiarem esses manifestantes e, com isso, pairava no ar um espírito revolucionário que exigia mudanças urgentes na condução política e social francesa. Essa ocasião de contestação, entre outras questões relevantes, marcava também o lugar de uma oposição à política da direita conservadora, mas que também se apresentava como oposição crítica ao que considerava um radicalismo da esquerda comunista. Estava sendo travada uma luta por liberdade de expressão, liberdade de pensamento, liberdade sexual; lutava-se por novas condições sociais que permitissem liberdade de escolhas; por uma sociedade democrática que enfrentasse suas opressões e exclusões; em resumo, tratava-se de uma luta que pretendia defender uma ética mais humanista para as relações de um modo geral.

Pensando nesses ideais é possível compreender, aqui, o termo revolução no seu sentido de revolta contra o poder estabelecido, mas também no seu sentido mesmo de mudança progressiva ou repentina de algo. Mais precisamente como movimento de desdobrar-se ou revolucionar-se. Por outro lado, sabe-se que nesse contexto revolucionário em que a França estava mergulhada, mobilizada no esforço de afirmação de uma identidade nacional - como povo democrático, defensor da liberdade, da igualdade e da fraternidade -, despontava também, inerente à defesa e ao enaltecimento do próprio, um certo apagamento do outro, um apagamento da importância da alteridade nessa construção, o que contradizia uma luta por democracia.

Atenta a essa aporia, parte da crítica intelectual francesa da época ao repercutir esse mesmo espírito revolucionário em seu discurso o faz também com vistas a uma crítica ao intenso etnocentrismo que se manifestava na cultura francesa, o qual revelava, entre suas consequências mais preocupantes, uma dificuldade crescente na recepção de algumas expressões culturais não francesas no país. Esse movimento crítico apoiou-se, em grande medida, em ideias como as apresentadas pela primeira geração do Romantismo alemão, resgatando, assim, um pensamento controverso que estava esquecido nos doloridos escombros da Segunda Guerra Mundial. Em consequência desse resgate, há também a retomada do trabalho de Walter Benjamin, em especial de sua tese de doutorado O Conceito de crítica de arte no Romantismo alemão, defendida em $1919^{2}$.

1. Nesse mesmo contexto, vale lembrar, a França já havia enfrentado a guerra da independência argelina e, mais tarde, a partir de 1968, acompanhou o movimento da Primavera de Praga e sua aniquilação pelos soviéticos.

2. O conceito de crítica de Walter Benjamin ganha contornos mais aprofundados devido à afinidade do pensamento benjaminiano com o idealismo mágico de Novalis e a obra de Friedrich Schlegel (SELIGMANN-SILVA, 2011). 
Como os primeiros românticos alemães sustentavam suas reflexões na necessidade que uma nação teria de buscar no outro, no estrangeiro, a sua renovação, ou melhor, de encontrar na experiência do e com o estrangeiro a sua atualização principalmente por se tratar de um processo de formação cultural de uma Alemanha que buscava também uma identidade nacional -, justificava-se plenamente o interesse de pensadores contemporâneos, críticos do etnocentrismo, pelas reflexões desenvolvidas por aqueles autores, na medida em que se tratava de um excelente contraponto aos valores nacionais vigentes. Era a defesa da ideia de que um movimento revolucionário só pode ser realizado na convivência com o outro; um modo de, nessa relação, permitir-se realizar e sofrer mudança sensível de pensamento apta a impulsionar novas ações, ou melhor, apta a atualizar ações que, por sua vez, mantenham constante o próprio movimento que as gerou.

Tratava-se, portanto, de um movimento de retorno à história do outro no caso, a Alemanha romântica -, para repensar a história própria. Um resgate fundamentalmente crítico. A partir desse diálogo, acreditava-se ser possível inaugurar um debate ético e político que alcançasse o objetivo de promover uma mudança urgente, uma transformação radical nos rumos do comportamento nacional. Como bem lembra Seligmann-Silva (2011), entre os principais autores envolvidos com esse movimento crítico (e autocrítico) estavam, entre outros, Michel Foucault, com Les mots et les choses (1966); Gérard Genette, com Mimologiques (1976); Tzvetan Todorov, com Théories du symbole (1977); Philippe Lacoue-Labarthe e Jean-Luc Nancy, ambos com L'absolu littéraire (1978), e mais adiante, em 1984, Antoine Berman, com o trabalho pelo qual se tornou conhecido: L'épreuve de l'étranger - no qual coloca em questão o etnocentrismo francês a partir de um discurso sobre a tradução.

O que era desconhecido, até bem pouco tempo, dos estudiosos que fundamentam suas pesquisas no pensamento bermaniano sobre tradução é o fato de que as contribuições desse autor para o cenário político-social da França, que estou chamando aqui de revolucionário, começaram a surgir antes do tardio 1984 portanto, antes mesmo de Berman tomar a tradução como "objeto" de reflexão. Em harmonia com o entusiasmo que levou estudantes franceses a deflagrarem a grande greve de maio de 68, Berman apresenta seu envolvimento com as reflexões dos românticos de lena nessa mesma década, enquanto ainda se graduava em filosofia pela Sorbonne. Nesse início de estudos, o autor francês, como é possível ler em suas primeiras publicações, tem sua atenção dirigida especialmente à leitura dos fragmentos de Friedrich Schlegel e Novalis. 
$\mathrm{Na}$ época, Berman registrou suas impressões em forma de diálogos, como vemos em $L a$ tâche de la poésie est simplement $(1967)^{3}$, e em forma epistolar, Lettres à Fonad El-Etr: sur le Romantisme allemand (1968) ${ }^{4}$, cartas "endereçadas" a um amigo, o poeta Fouad El-Etr, com quem tinha em comum o projeto de escrever sobre os primeiros românticos alemães e, assim, reapresentá-los à cena intelectual francesa. Esse projeto começou a ser concretizado com a fundação, em 1967, de uma revista à qual deram o nome de La Délirante $e^{5}$ especializada em ensaios sobre o Romantismo alemão e em traduções de obras de autores desse período. As cartas, bem como o diálogo, foram publicadas nessa revista; nelas Berman apresenta uma leitura daquele importante momento vivenciado pelo povo francês, defendendo a ideia de que se fazia necessária uma poética, ou um pensamento poético, para que fosse possível qualquer tipo de transformação cultural, social e política numa sociedade. A partir disso, fundamentará seu pensamento e a realização de suas atividades nesse movimento de reflexão romântico, que para ele marcaria profundamente uma condição revolucionária e representaria a sua constância necessária no pensamento moderno, ou que se quisesse realmente moderno.

Uma dessas atividades, que Berman coloca em prática juntamente com Fouad El-Etr, nesse mesmo espírito romântico, foi a criação de um grupo de teatro, o Théatre d'Aran. Esse grupo, por sua vez, também elaborou um projeto de revista, Les cabiers d'Aran, cujo único volume de que se tem conhecimento foi editado em 1969. A ideia dessa revista (programa/projeto) não era somente a de apresentar a companhia e seu funcionamento, mas, principalmente, a de convidar o público interessado a utilizar seu espaço mais efetivamente e de um modo bastante singular: através da indicação de textos que seriam publicados nos futuros números da revista e que, também, serviriam como suporte para a realização dos espetáculos teatrais. Com isso, o grupo não pretendia apresentar programas de modo tradicional apenas com o objetivo de dar ao espectador informações técnicas sobre o espetáculo como se costuma fazer nas apresentações de teatro. Ao contrário, nessa proposta de programa criativo o espectador faria - assim por dizer - parte da realização de cada espetáculo; ou melhor, faria parte do movimento de criação de cada espetáculo. Na revista de número um, Les Cabiers d’Aran (1969, p. 7, grifo do autor), lê-se a

3. Esse diálogo, A tarefa da poesia é simplesmente..., foi traduzido por mim e por Marcos Siscar para o português brasileiro, tradução publicada, em 2014, na revista Remate de Males vol.34, no 1 . p.213219.

4. Uma tradução inédita desse texto para o português brasileiro, de minha responsabilidade, será publicada em breve pela Zazie Edições, em formato eletrônico e gratuitamente, na coleção Pequena biblioteca de ensaios, com acesso em http://www.zazie.com.br/pequena-biblioteca-de-ensaios/.

5. Hoje uma editora, que continua sendo dirigida pelo poeta franco-libanês Fouad El-Etr. 
explicação sobre essa nova concepção de programa: "Não ficar preso a programas, mas unir-se aos temas e aos textos que são figura e destino. Cada espetáculo nasce do encontro de um tema, de um texto, ou do traço que esse tema ou esse texto deixaram em nós ${ }^{6 \prime}$. Ou seja, não haveria de fato programa, no sentido tradicional do termo, porque a experiência não partiria de um plano originalmente pré-elaborado; o plano surgiria da experiência conjunta, que, por sua vez, daria vazão a novos planos, e assim sucessivamente ${ }^{7}$. Anunciava-se, portanto, o que é possível compreender como uma defesa da convivência.

Essa maneira de se pensar a relação entre teatro e espectador também antecipa a forma de sistematicidade que Berman buscará na obra antes de traduzi-la, no melhor estilo romântico: a tradução se produz produzindo a sua própria teoria, seguindo, assim, a proposição de Nancy e Lacoue-Labarthe (1978, p.22) ao lerem o romantismo como "a própria teoria como literatura", ou seja: "a literatura se produzindo ao produzir a própria teoria".

É também nesse sentido que o Théâtre d'Aran realizaria o desejo de não se fechar em torno de si próprio para criar os espetáculos. Num movimento caracteristicamente romântico, o grupo sairia de si a fim de buscar instrumentos fora de si, para, depois, na união desses dois centros - o interno e o externo -, realizar os espetáculos. Um jogo de leitor e obra, de tradutor e obra.

Ademais, é importante destacar a leitura bermaniana do conceito de moderno, que como vimos só poderia ser determinado enquanto tal se fosse tributário de uma reflexão com bases românticas. Em Lettres à Fouad El-Etr, Berman (1968, p.15) explicita uma diferença de concepção para os termos Moderno e moderno - distinção bastante significativa para o seu futuro pensamento sobre tradução -, quando escreve que entre o ideal moderno apresentado pelos românticos - a reflexão considerada como uma elevação a segunda potência -, especialmente por Schlegel e Novalis, "e as formalizações áridas dos Modernos", há um abismo. Para ele, "[p]or mais familiares que tais formalizações nos possam parecer [...], elas não significariam para os Românticos mais do que um empobrecimento, uma simples limitação de conteúdo" (BERMAN, 1968, p.15).

É assim que Antoine Berman criará ao longo desses primeiros anos de leituratradução, ou tradução-leitura, do romantismo alemão uma relação simbiótica com esse pensamento, como ele mesmo irá definir anos depois em L'épreuve de l'étranger (1984).

6. (Todas as traduções cuja autoria não estiver especificada são de minha responsabilidade).

7. Para manter a ideia de produção conjunta, nenhum dos textos apresentados na revista leva a assinatura do seu autor, mas, por intermédio da diretora do grupo e esposa de Berman, Isabelle Garma, sabe-se que dois dos ensaios nela publicados são de autoria de Antoine Berman. São eles: Il faut trouver avec le théâtre... e Les mains. A revista também era dirigida pelo autor. 
Berman, na sua juventude, estava fascinado pelo pensamento primeiro romântico, especialmente, como vimos, por sua característica revolucionária, que seria para ele mais do que simples característica; segundo ele o romantismo era a própria revolução. Essa revolução desenhava-se através do movimento circular de reflexão elaborado por Friedrich Schlegel, que, por sua vez, faz dele uma releitura do conceito alemão de Bildung, enquanto movimento de formação cultural; um eterno, e circular, sair de si para buscar no outro, no seu diferente, a possibilidade de transformação, de atualização, de potencialização do próprio. Para Berman (1968, p.23), no seu modo de entender essa forma circular:

O círculo romântico, que existiu algum tempo em lena, era absolutamente aberto e absolutamente fechado, com múltiplos centros de gravidade. Aqui a poesia era poesia de todos os dias, uma febre continuada. As oposições e as diferenças tão temidas se suprimiam por um tempo no puro presente do círculo.

Como é possível notar, essa ideia de círculo nos apresenta um centro, mas também uma infinitude de raios. Uma multiplicidade infinita de raios cujo centro é comum a todos eles. E, em cada raio, um ponto está no infinito e o outro no centro pelo qual se une a todos os outros raios; ao menos nesse ponto único se forma um Todo. Para Berman $(1968$, p.26), era desse modo que Novalis,

[...] alma fluida, compreendia a síntese poética - aquela do mediato e do imediato, do realizado e do irrealizado, de Deus e do homem, da natureza e da arte, do passado e do futuro, da poesia e da não-poesia - como uma dissolução das oposições em um presente perpétuo e ilimitado: "quando tudo aquilo que era estrangeiro fosse dissolvido e absorvido no elemento da poesia surgiria o real absoluto".

Na sequência, o autor não deixa de chamar a atenção para o fato de que "Não era sem apreensão que citava essa frase célebre" (BERMAN, 1968, p.26), alertando para a necessidade de um olhar cuidadoso e crítico - como deveria ser o de todo leitor - ao movimento que tanto o fascinava.

Permitam-me interromper, aqui, de modo abrupto, a leitura do jovem Berman do movimento revolucionário primeiro romântico. Mesmo correndo o risco de um recorte injusto na própria leitura crítica do autor ao nos apresentar pensamento tão denso, tão cheio de nuances; recorte que estimulou leituras tão aprofundadas e honestas como as de Benjamim, quanto leituras apressadas que acabaram, muitas vezes, por responsabilizar esses pensadores por questões que aparentemente não estavam sequer delineadas no horizonte das suas reflexões. Porém, o que me interessa marcar, neste momento, é o quanto esse movimento circular de reflexão colocou em estado febril o pensamento de Antoine Berman em relação ao desenvolvimento de uma ética, que a meu ver será pautada, mais adiante - após uma problematização 
dessas primeiras assimilações românticas -, por um discurso de e pela convivência, um discurso de defesa por uma convivência radical.

Após ter vivido seu período de formação durante a conturbada e revolucionária década francesa, mergulhado nas traduções românticas, o germanista Antoine Berman vai passar por nova revolução reflexiva, na qual o ideal romântico, tão europeu (?), será virado do avesso pelo estrangeiro, pelo bárbaro latino-americano. O autor irá de fato atualizar sua leitura romântica através da experiência de vida e da experiência como tradutor. Reflexão e experiência, num movimento circular.

Antes de seu doutoramento, mais ou menos início dos anos 1970, Berman mudou-se para a Argentina e por lá viveu quase cinco anos bastante intensos de sua vida. Nesse período portenho, o povo argentino, composto por trabalhadores cuja maioria era de autóctones e gauchos, lutava fortemente contra um longo regime militar ditatorial para construir um país livre e soberano em que prevalecesse a justiça social - lembrando que aqui também não se tratava de uma luta absolutamente de esquerda, ao menos não de uma esquerda tradicional como a imposta pelos partidos comunistas da época. Nesse cenário, o populista Juan Perón surge como o líder perfeito para defender os anseios populares; o movimento peronista, então, ganha dimensões incalculáveis e persiste vigoroso por longos anos, marcando fortemente a história argentina.

Durante o período em que Péron esteve à frente da Secretaria de Trabalho e Previdência, em 1943, conforme registra J.L.B. Beired (1984), ele implementou medidas que beneficiaram muito os operários. Essas medidas deram ao povo trabalhador mecanismos para a negociação de convênios coletivos, buscando torná-los mais efetivos; de indenizações em caso de demissão, alterando as normas trabalhistas; de férias remuneradas; e de ampliação do sistema de aposentadoria para operários da indústria e do comércio. Com isso, desvelam-se os motivos possíveis que podem ter feito a classe trabalhadora fechar os olhos para qualquer tendência manipuladora e opressora de Perón, o que não é totalmente estrangeiro a nós brasileiros, que vivemos um exemplo muito parecido na era Vargas.

Esse movimento desperta enorme fascínio em Berman, que relatou essa experiência argentina, em conjunto com Isabelle Garma, no texto Trente ans de luttes nationales, publicado em 1976, no seu retorno à França. Para os autores franceses, a escolha popular argentina não tinha, como vimos, nada de ingênua, pois, segundo eles, aquele povo sabia bem o que queria, e escolheu um líder que já apresentava uma política social que se encaixava nas suas necessidades. O peronismo, na opinião deles, parece ter sido o que levou Juan Péron ao poder, e não o contrário. Havia, 
nesse movimento, uma voz popular que rompia com as regras estabelecidas, antes mesmo de seu líder subir ao púlpito.

Outra característica importante que Berman (1976) encontra no movimento peronista é sua construção a partir de inúmeras contradições, que geraram uma interessante bipolaridade política na Argentina: os peronistas e os antiperonistas. Nessa lógica, o antiperonismo era composto por partidários comunistas unidos a partidários de direita; por outro lado, dentro do próprio peronismo também havia uma divisão de esquerda e direita - essa ambiguidade do peronismo é muito semelhante, embora por motivações diversas, ao movimento do primeiro romantismo, que inspirou tanto atitudes reacionárias quanto progressistas. Tal complexidade é o que nos faz entender por que foi dispensável para Berman elaborar uma compreensão da sua lógica. $\mathrm{O}$ autor prefere considerar menos relevante marcar pontualmente as contradições desse movimento - não era claro para ele o ponto em que elas surgiam e depois se diluíam -, para entender que foi justamente por conta delas que houve o irrompimento das massas populares e, com isso, revelaram-se conflitos internos que até então estavam mais ou menos latentes no país, e esses sim mereciam atenção. Nesse sentido, o desvelamento das contradições sociais, políticas e culturais possibilitou um diálogo e, com isso, enriqueceu a formação nacional, ao menos o seu aprendizado.

Desse modo, é notável que Berman reconheça nesse período a criação mútua de um movimento e de uma consciência popular; portanto, um movimento reflexivo. $\mathrm{O}$ movimento peronista, na visão desse autor, teria também, por isso, um caráter de formação; formação de uma sociedade e de um povo, de uma cultura, de uma nação.

Na sequência da sua reflexão, será dada bastante atenção a um dos conflitos surgidos a partir do movimento peronista, o conflito entre o que se considerava barbárie (povo, autóctones e gauchos) e o que se considerava civilização (oligarquia, formada por camadas europeias e norte-americanizadas). Segundo Berman, a imprensa internacional, naquela época, falava com ironia e com certo despeito sobre a Argentina, pois a tinha como um país "rico", pleno de pessoas educadas, que deveria já ter alçado voo como o Canadá e a Austrália; era como se não perdoasse a Argentina por permanecer como um país subdesenvolvido enquanto tinha todos os trunfos ao seu dispor. Para o autor francês essa era uma visão no mínimo insensata, porque esse tipo de observação desenhava a Argentina como um subpaís europeu, e não como uma nação latino-americana pertencente ao terceiro mundo. Por conta disso, o que, na sua opinião, alguns colonizadores faziam questão de esquecer era que, naquele momento, tratava-se de um país absolutamente dependente, que precisava travar uma luta constante contra imperialistas. A construção do nacional para países 
colonizadores e países colonizados implica uma energia motriz absolutamente diversa, pois uma coisa é afirmar uma identidade; outra, bem diferente, é tirá-la do apagamento ao qual foi submetida. É preciso ter voz para se fazer ouvir. Isso reflete uma atitude etnocêntrica preponderante na França, e na Europa de um modo geral. (BERMAN, 1976)

Essa mudança importante de perspectiva é fundamental para Berman colocar a lição aprendida do primeiro romantismo em questão, fazendo-o questionar seu próprio lugar de crítico do etnocentrismo - sendo ele, antes de tudo, e enquanto europeu, a voz daqueles a quem sempre foram dados ouvidos -, impulsionando-o, assim, a reagir como um militante revigorado a partir do seu discurso sobre tradução.

O autor francês considerava que desnudar as oposições e os conflitos que formavam o núcleo da história da Argentina tenha sido "o choque revolucionário operado pelo peronismo" (BERMAN, 1976, p. 1244). Devemos pensar esse choque revolucionário, ou choque de virada, como algo que impulsiona ou estimula o/ao diálogo entre partes opostas e conflitantes, que as coloca em relação, em convivência, e que, também, enquanto choque, impulso, não termine por limitar essa virada, estagnando-a. No choque revolucionário a que Berman faz referência notamos duas ações simultâneas: além de mudar radicalmente uma posição estanque, naturalizada, também dispõe essa mudança em movimento contínuo, porque as oposições (sempre presentes) em constante diálogo promovem constantes transformações, revoluções, viradas.

No caso argentino, como desenvolve Berman (1976), as oposições não se resumiam a uma luta de classes, e nem mesmo poderiam ser reduzidas a uma luta nacionalista ou guevarista. O peronismo teria adotado, na verdade, uma política de aliança de classes, na tentativa de um Estado soberano que promovesse a justiça social, mas que também absorvesse a burguesia, o lado que se opunha a esse movimento. Perón, na aliança, procurava, na visão bermaniana, uma possibilidade de convivência entre os opostos, através de um proletariado unido e sindicalizado e uma burguesia industrial nacional. $\mathrm{O}$ que poderia soar utópico, ou não.

A partir dessa visão do cosmo peronista, em que nos é apresentada a constituição e o processo de formação do movimento, Berman faz um recorte com o objetivo de analisar o núcleo gerador desse espírito revolucionário, onde se encontra a força que possibilita a existência de um espírito popular com todo potencial para construir seu espaço. Essa força, segundo Berman, é gerada pela capacidade de convivialidade que permeia algumas camadas sociais da América do Sul de um modo geral, mas, principalmente, diz respeito à mentalidade de um povo, ao seu modo de pensar. (BERMAN, 1975). Podemos agora começar a refletir, junto ao autor francês, sobre uma ética da convivência que ele começa então a esboçar. 
Em Maté et communication (1975), Berman demonstra seu interesse por um saber estar juntos que é constituído pela convivialidade. Esse saber, segundo o autor, só pode ser generoso, espontâneo e aberto, e a partir dele a vida social ao invés de promover um apagamento do indivíduo, deve permitir que ele exista, permitir que se realize e que se expresse com liberdade. A convivialidade é a experiência do partilhar especialmente as diferenças. Isso significa, para Berman, um socialismo espontâneo, afetivo, e para que essa convivialidade permaneça ela precisa encarnarse em "formas sociais concretas e cotidianas" (BERMAN, 1975, p.810). Formas que praticamente não existiam mais nas sociedades industrializadas, mas eram, segundo o autor, muito vivas em países da América do Sul, embora ameaçadas pela introdução do sistema capitalista nesses países. Isso fez com que as pessoas, especialmente aquelas que viviam nas pequenas cidades, começassem a sofrer uma perda de identidade, mas ao mesmo tempo a lutar contra o imperialismo ocidental, luta que as levaria na direção da reafirmação de seu modo de vida tradicional. Como vislumbramos na leitura que Berman (1976) fez do peronismo.

Parece estranho que especialmente esse autor tenha construído um discurso de defesa do tradicional, da tradição. No entanto, o que parece ser uma contradição no seu discurso é na verdade uma afirmação de determinada ética. Aqui, ao tratar de convivialidade na América do Sul, Berman (1975) estava falando sob o ponto de vista daquele que sofre repressão, que é também aquele que tem por hábito oferecer generosidade e abertura e, por isso, precisa encontrar instrumentos de defesa contra o apagamento da sua própria identidade, como já foi dito anteriormente. $\mathrm{O}$ autor francês tem plena consciência de que o problema da América do Sul não é o de se adaptar aos esquemas da cultura europeia, mas de adaptar esses esquemas - o que eles têm de universal, como a ciência, a técnica, etc. - às suas próprias formas de existência. Para a existência plena de algo universal - nesse caso conceito vindo do outro -, o individual - o próprio, - tem que sobreviver. A tradição, na América do Sul, não é aquela que se impõe ao outro.

Berman, nesse texto de 1975, reconhece o grande número de estruturas conviviais já existentes na América Latina, e defende que essas estruturas devem mesmo resistir à penetração da cultura ocidental estrangeira. Por outro lado, para ele era fundamental que a visada ética desse movimento de defesa fosse pautada por uma ética da convivência, desse modo, essa recusa ao outro não poderia absolutamente recair num nacionalismo obtuso; ela deveria, assim, integrar o melhor da tradição científica, técnica e revolucionária europeia - considerando que a Europa era o berço da ciência e da revolução -, reforçando que essa tarefa se revelaria árdua, e que nesses casos sempre é assim. A Europa, por sua vez, segundo Berman, não tinha mais nem estrutura convivial e nem mentalidade convivial. Para ele, enquanto 
inventora das comunas, dos sovietes, do socialismo e do comunismo, a Europa vivia mergulhada numa vida cotidiana e num sistema institucional claramente antissocialista e anticonvivial. Nesse cenário, o problema a ser enfrentado por essa Europa seria o de precisar inventar estruturas sociais conviviais. Tarefa tão árdua quanto a de defendê-las. Ainda assim o autor reconhece que seria possível para a Europa buscar auxílio na sua própria bistória, dado que haveria nela uma antiga tradição revolucionária (que poderia ser também, obviamente, um obstáculo) e o caráter insuportável do não-convivial. Com isso, surgiria uma relação dialética entre o nascimento de uma nova mentalidade convivial e a aparição de novas estruturas conviviais. No entanto, nas palavras de Berman (1975, p.810, grifo do autor),

[...] a convivialidade é real apenas na invenção de uma nova vida cotidiana. Sendo a vida cotidiana um comércio continuo com os homens e os objetos, quais seriam os objetos para reunir os Europeus? No momento atual, cada objeto do mundo capitalista é um objeto-deseparação (o café, o jornal, a televisão, etc).

Na Argentina, lembra Berman (1975), de acordo com princípios comuns aos povos primitivos, as formas conviviais tradicionais e populares se articulavam em torno de objetos. Dois desses objetos, segundo o autor, seriam os mais emblemáticos para demostrar o movimento das formas conviviais: o violão e o mate. Quanto ao violão, e isso é muito fácil identificar também entre nós brasileiros, é um instrumento capaz de agregar pessoas ao seu entorno quando executado, representando assim um objeto social e de convívio. Ninguém toca absolutamente sozinho, a não ser que esteja ensaiando. Já na Europa, observa Berman, a relação espectador-ator, a que os europeus estão habituados, mostra uma tendência empobrecedora, porque existe nessa relação "uma divisão exageradamente aguda dos papéis que não permite uma verdadeira coletividade e uma verdadeira partilha" (BERMAN, 1975, p.810). Entre os argentinos e os europeus, há ainda outra diferença de fundamental importância para que esse instrumento articule a convivência: é que o número de argentinos das mais diversas classes sociais que tocam o violão é bastante grande, então é raro que numa reunião apenas uma pessoa monopolize o instrumento. Ele passa de mão em mão. Em uma reunião, a monopolização dos violões por uma só pessoa, seria vivida como uma perda, um empobrecimento, no modo bermaniano de compreender essa questão. Ao passar de mão em mão os violões se respondem e se correspondem ${ }^{8}$. Segundo o autor : "[...] a guitarreada forma uma reunião humana em que se conjugam

8. Aproveito para chamar a atenção, aqui, para a reverberação dessa noção de correspondência numa expressão que Berman usará, em Pour une critique des traductions (1995, p.94), para designar a tarefa da tradução: faire-euvre-en-correspondence, em que o autor jogará com a ambiguidade do termo correspondência, no sentido tanto daquele que corresponde a algo quanto daquele que troca correspondência, dialoga com algo ou alguém. 
harmoniosamente a expressão e a comunicação, a atividade e a passividade, o individual e o coletivo" (BERMAN, 1975, p.810, grifos do autor). O que é outra forma de dizer que a guitarreada abre espaço para o diálogo entre os divergentes, vale para os dois lados de uma mesma moeda.

Outro objeto de convivialidade que chamou a atenção de Berman (1975) foi o mate, mais especificamente a consumação do mate, não apenas caracterizada pelo fato de ele ser tomado quase sempre em grupo (podemos fazer isso com o café também), mas também em função da natureza particular do conteúdo e do recipiente ("a alma e o corpo, sem cisão"), que dá lugar a uma forma convivial que acabou adentrando profundamente a vida cotidiana. Primeiramente, na Mateada há apenas uma bomba e uma cuia para todo o grupo. Assim, a cuia será partilhada pelos participantes reunidos enquanto durar a mateada. Uma das pessoas do grupo, sempre a mesma numa mesma reunião, será a responsável por preparar a erva e dar início à mateada. É ela quem vai encher o recipiente e também vai ser a primeira a saborear o mate. Depois, vai encher de novo o recipiente para passálo adiante, ao vizinho. Este último, após tomar todo o mate, vai voltar a cuia ao responsável, que irá de novo completá-la com água fervente para encaminhá-la ao participante seguinte, e assim sucessivamente, criando uma estrutura em comum e circular. Desse modo, a passagem do mate de pessoa em pessoa, por intermédio de um responsável, cria uma roda, um círculo, ela faz um movimento circular. "O mate é em si uma experiência de partilha" (BERMAN, 1975, p.811, grifo do autor). Para Berman, há ainda nesse movimento algumas características relevantes e exemplares de racionalidade e bumanidade do trato popular. Em primeiro lugar, há o fato de não ser preciso agradecer ao responsável toda vez que ele lhe passa a cuia (só se faz isso como modo de dizer que não se quer mais beber o mate); quando se serve o mate, a bomba deve estar voltada na direção de quem vai recebê-la, porque se estiver voltada na direção oposta, a pessoa que precisará ou modificar a posição da bomba, podendo bloquear o conduto com mate, ou virar a cuia para si, arriscando derrubar a água quente em si mesma, queimando-se. A responsabilidade para com o outro, aqui, vai além do que um simples gesto mecânico cordial.

Como o mate fundamentalmente é tomado em comum, ele nos mergulha numa temporalidade particular, nos introduz, segundo o autor, em um tempo partilhado, ou melhor, num tempo compartilhado. Esse tempo é longo, visto que não há um limite biológico que nos impede de consumir o líquido; é um tempo reunido, marcado pela periodicidade da consumação do mate na roda (eu não tomarei mais do mate enquanto todos os meus companheiros de roda não tiverem saboreado da mesma erva). A absorção do mate marca também um momento ao mesmo tempo estendido 
e pontual no qual "se harmonizam a atenção aos outros e a minha própria consumação: de fato, o mate não se bebe, mas suga-se, saboreia-se" (BERMAN, 1975, p.811, grifo do autor). Temos, aqui, um aproveitamento do convívio. Berman diz, também, ser impossível beber o mate num único gole como podemos fazer com um café ou com uma taça de licor, por exemplo, porque tomar um mate, matear, no seu modo de entender, é

[...] um momento individual intenso. Mas, ao mesmo tempo, esse momento que me é dado para saborear o mate é um momento limitado, porque os outros o aguardam. Matear me ensina, então, a viver a difícil união entre o individual e o social. (BERMAN, 1975, p.811)

Nota-se na leitura de Berman que, para ele, a consumação do mate se dá no movimento circular e na passagem periódica do recipiente, nesse trânsito que por sua vez dita o ritmo no qual os participantes compartilham da mesma experiência. Esse longo tempo, segundo o autor, constrói-se em dois outros tempos, o tempo de falar e o tempo de calar. É o ato de consumação que determina tanto os momentos de silêncio quanto de fala (parole) de cada um: quando pego o mate para tomar, esse é evidentemente o momento em que me calo, em que me recolho e me volto ao silêncio, à reflexão. E esse é o momento em que qualquer outro dos participantes pode eventualmente falar. E mesmo que todos se calem e o silêncio se instale, observa Berman, é quase impossível que se sinta opressão e opacidade, porque o mate ainda continua a rodar e só o fato de esse trânsito não se interromper assegura um mínimo de comunicação entre os presentes. Ocorre que, havendo convivência a comunicação não se interrompe, o que nos faz pensar que comunicar está muito além de um simples ato de informar algo a alguém. Comunicar, nesse sentido, é troca, é diálogo (porque no silêncio também há diálogo), é partilha, sempre.

A mateada é, portanto, para Berman (1975), um veículo de comunicação. A forma circular não é para conduzir a algum tipo de ritual ou de cerimonia, vez que nada há de sagrado nessa reunião, mas é, sim, considerada por quem dela participa, um momento privilegiado do dia, como um encontro profundo que cada um dos que ali se encontram espontaneamente sente o dever de respeitar. Trata-se, portanto, de uma relação baseada no respeito ao outro. A forma circular, nos lembra Berman, é provavelmente a forma mais antiga de ajuntamento humano, e que ele toma como a estrutura mais socialista e mais democrática que quaisquer outras. É a partir da experiência da mateada que Berman justifica essa afirmação. E destaca, de saída, que em um círculo nenhum participante ocupa uma posição privilegiada, uma vez que todos estão sentados frente a frente e ninguém fica para fora nem isolado; além disso, continua, um círculo impede, ou torna difícil a formação de subgrupos fixos, duráveis. No decorrer desse encontro, cada um está presente para o outro, 
todos estão presentes para cada um e cada um para todos; portanto, a mateada não encoraja os apartes, antes almeja uma intimidade coletiva. Enfim, é uma cerimônia que se repete, mas, ao mesmo tempo, não é uma cerimônia fixa, e o círculo permanece aberto - isso quer dizer que eu posso sair do círculo, voltar para ele, me levantar, me sentar.

Embora observe na mateada um cerimonial marcado por regras, Berman não o vê, nem o experimenta, como a cerimônia do chá inglês, por exemplo. Para ele, essa forma convivial revela-se de fato um veículo de comunicação, no sentido da troca e do diálogo, e é isso precisamente que faz de seu objeto (o mate) uma palavra que fala das relações amorosas, e que dá lugar a todo um código do mate. Berman (1975) oferece um exemplo: se um rapaz vai à casa de uma moça com a intenção de cortejá-la, e ela lhe serve o mate com água quente e com a bomba voltada para o rapaz, isso significa que ela o aceita como um pretendente. Caso a bomba aponte para um dos lados, indica que ela já tem outro pretendente. E se a água com que a moça vai encher a cuia estiver morna, o rapaz deve ler nesse ato uma manifestação de desprezo.

Sendo assim, o objeto que articula a forma convivial, por si só, sendo de interesse em comum, já justifica o enfrentamento da convivência. "A mateada é fundamentalmente uma 'estrutura de acolhimento' e sua atmosfera é claramente antirepressiva" (BERMAN, 1975, p.813).

$\mathrm{O}$ que quero de destacar, a partir disso, é que o discurso ético de Berman claramente desenha uma ideologia "antirepressiva", que se revela contrário a determinada ideologia dominante, para, com isso, aprender a real convivência num espaço ideológico pautado pela inclusão, pela democracia, portanto. Berman busca, na Argentina, as bases para o seu discurso ideológico, como vimos, a partir do oprimido, não da classe dominante, e o oprimido em questão é o popular, o autóctone, a tradição cultural primitiva. É esse movimento de retorno à tradição, no contexto argentino, que me parece fundamental para que ele possa construir reflexivamente uma ideologia não dominante. Ao final da sua análise da estrutura da mateada, temos uma pista desse entendimento de Berman (1975, p.815):

O retorno ao mate torna-se assim uma das formas de protesto concreto contra o processo de colonização cultural. Através desse consumo "ideológico" do mate é toda a estrutura convivial da sociedade argentina que busca manter-se e preservar-se.

Se pensarmos na ideologia do romantismo alemão, por exemplo, que também nasce da ideia de revolução - responsável inclusive por um pensamento em defesa da constante formação cultural, social, política e, principalmente, linguística de um país em construção (Bildung) -, o que se tem é uma ideologia que permanece circunscrita, 
de certo modo, a uma minoria definitivamente não popular, que conserva o monopólio de um pensamento moderno filosófico-artístico. No caso do movimento alemão, o que se tem é um pequeno grupo de intelectuais que enuncia e define as regras do como as coisas devem ser. Essa característica, evidentemente, não constitui por si um argumento para menosprezarmos, em absoluto, esse que foi um movimento tão crucial para o surgimento de um pensamento moderno e revolucionário, como é o caso de muitos autores da geração de Berman; mas o fato de reconhecermos isso conduz nossa atenção para a necessidade de recontextualizar e atualizar essas ideias românticas na contemporaneidade. A partir do momento em que busca justamente no popular, no oprimido, as bases para construir sua ideologia, Berman mostra que seu caminho parte da mesma fonte, mas que as trilhas são outras, e outra a direção, como ele entende que a urgência do momento pede.

Ao propor a fuga de qualquer tipo de atitude e de ideologia antirepressiva, o autor francês busca um equilíbrio que traz para o diálogo o outro no seu sentido pleno, não apenas o não-eu, ou, o outro-eu, mas o Outro propriamente dito. Não entendo que, dessa forma, Berman esteja excluindo dessa construção, dessa proposta de diálogo, o não-eu, o outro-eu, o alter-ego, enfim, aquilo que se pode entender como o próprio avesso muitas vezes invisível. Ao contrário, ele quer dar um passo adiante dessa discussão; e o passo além leva-o a buscar sua desconstrução, leva-o a deslocar os pontos dos raios não para o único centro do círculo, mas para as suas margens, em que cada ponto é seu próprio centro em diálogo, não construindo com os outros pontos da mesma circunferência uma relação hierárquica. Assim, se traria de volta, na volta a si, não apenas um eu transformado, potencializado, mas o eu outro e com o outro, com algo do Outro, não apenas aquilo que dele transformo em meu. Para isso, primeiro é necessária a experiência de um outro radical, de um outro vencido, e quase sempre esquecido/apagado na história, e não do vencedor.

Quando promove esse deslocamento de centro, Berman dá ao outro a mesma relevância do próprio, buscando evitar a hierarquização, fazendo com que se torne quase impossível distinguir nessa relação um ponto de partida, pois, no seu círculo, o eu e o outro ocupariam diversos pontos na circunferência, e ao saírem das margens apenas atravessariam e cruzariam esse centro que se tornaria um lugar de passagem, não um ponto de encontro, não um ponto de chegada, onde as diferenças se dissolvem. Isso trará para ética bermaniana um ponto de vista, portanto, que não tem o eu, ou o si mesmo, necessariamente como ponto de partida ou como aquele que lucra, que se afirma sozinho na relação com um outro.

A partir disso, podemos pensar que o algo do outro que nos alimenta na relação pode continuar sendo algo de outro, no mesmo espaço que o eи ocupa, sem deixar de 
transformá-lo, mas também sem deixar de transformar-se na relação. As diferenças é que são afirmadas, que continuam convivendo juntas em comunidade, mas sem perder a individualidade; é um trânsito constante entre o individual e o coletivo (entre singular e plural, se quisermos dar um pulo no tempo para pensarmos juntos com Jean-Luc Nancy); e nesse trânsito ninguém deveria sofrer apagamento, porque se trata sempre de sujeito histórico.

Convencido da importância da ação conciliadora que envolve uma postura convivial, ou uma ética da convivência, como estou chamando aqui, Berman se concentrou também em romancistas argentinos cuja escrita procurava romper com esse domínio estrangeiro, trazendo à cena a linguagem popular e os dialetos, plenos de oralidade, e criando, com isso, um tipo de miscigenação linguística que reivindicava um espaço também para o próprio, que estava sendo apagado ao lado daquele outro dominante. A língua local, que simbolizava uma identidade nacional, estava sendo apagada devido à força de inserção da cultura do colonizador europeu. No texto $L a$ voix des sans-voix (1980), Berman nomeia os quatro autores que melhor representam para ele essa peculiaridade da literatura latino-americana, cuja abordagem se dá a partir da relação entre história e ficção. São eles: José Maria Arguedas, Manuel Scorza, Garcia Marquez e Roa Bastos. Mais tarde, acrescentará ainda a esses autores os nomes de Roberto Arlt e de Guimarães Rosa. Dentre esses autores, Berman foi tradutor para o francês de três: Scorza, Bastos e Arlt. São autores que, segundo Berman, na medida em que alimentavam essa forma de escrita, traziam para dentro dos romances a lógica das estruturas conviviais latinas.

Para esses autores, na história da América Latina a inolvidável presença da crueldade é uma realidade incontornável, e faz que se torne para eles impossível não se questionar e não colocar em questão "a relação da ficção literária com a textura concreta e, ao mesmo tempo, ficcional da realidade histórica" (BERMAN, 1980, p.4, grifo do autor). E é essa realidade incontornável que leva Berman a afirmar que essa história é também "uma história negada, abortada", uma história que é "infâmia e eternidade, maldosa eternidade repetitiva da infâmia" (BERMAN, 1980, p.4). Segundo o autor francês, Roa Bastos, por exemplo, em Moi le suprême ${ }^{9}$, fala, nesse sentido, sobre o nada, "a vida não vivida como vida, a irrealidade como realidade" (BERMAN, 1980, p.5). Berman faz referência a esse mesmo nada, quando defende em seu ensaio La traduction au manifeste (1984) que a tradução "é relação [convivência], ou não é nada" (p.16, grifo do autor).

É também essa realidade irreal, tomada como tarefa pelos romancistas argentinos, o que desperta o interesse e a reflexão de Berman, especialmente porque ele vê,

9. Yo el supremo, a tradução para o francês é de Berman. 
nessa tarefa, uma tentativa de "captar e de conjurar essa realidade irreal no plano da ficção" (BERMAN, 1980, p.4). Para o autor, para além de "pura fixação, pura repetição, puro nascimento ou fundação abortada" (BERMAN, 1980, p.4), existiria, nessa realidade irreal, uma coexistência quase simbiótica de tempos, no sentido de uma "dimensão que não chega a ser história [...], progressiva autoprodução de si" (BERMAN, 1980, p.4), mas que seria uma iminência eterna dela. Ao movimento temporal o autor denominará pura simultaneidade caótica - tanto de fases quanto de conteúdos. Trata-se de um movimento que se mostra juntamente "tempo-daconquista, tempo-da-moderna-sujeição, tempo primitivo, tempo imperial, tempo feudal, tempo capitalista, tempo linear, tempo cíclico, etc." (BERMAN, 1980, p.4). Em outras palavras, os romancistas argentinos buscavam escrever a partir do que identificavam como a negatividade da história; além disso, tinham como horizonte a ideia de que só seria possível o conhecimento de um presente vivo no instante da posse desalienada de todos esses tempos possíveis reunidos. Essa utopia, que Berman admite ser a ideia de uma possessão desalienada, é a obsessão dessa literatura (BERMAN, 1980). Ele irá então concluir dizendo:

E é a partir disso que se desdobra sua função sobredeterminada: em um continente onde o espaço político e histórico permanece majoritariamente barrado, a criatividade mergulha no espaço literário. A literatura latino-americana tende a assumir o papel das ciências humanas, do ensaio, da crítica, da filosofia, e até mesmo da educação, para se colocar como a voz dos sem-voz. Há nisso uma pretensão que, curiosamente, a leva não na direção de uma maior legibilidade, mas para a produção de obras cada vez mais captativas, cada vez mais totalizantes e reflexivas, capazes de rivalizar vitoriosamente com aquelas do "Centro" (Europa e Estados Unidos). Processo uma vez mais hiperbólico que comporta certos riscos e pode exceder o campo de toda literatura. (BERMAN, 1980, p.4, grifos do autor)

Nesse espírito literário, quando retorna à França, Berman irá propor uma tradução de Roberto Arlt como forma de protesto concreto à resistência etnocêntrica francesa representada, naquele momento, pela força das belles lettres, naturalizada em sua cultura especialmente pelo classicismo francês; um momento em que toda tradução deveria transformar o texto traduzido em um texto que soasse francês. Quando Berman tenta permear o francês padrão de uma poética ${ }^{10}$ não-europeizante, aquela do texto "rebelde" argentino, encontra forte recusa editorial, deparandose com uma crítica que vê, no resultado de sua tradução, um texto francês "mal resolvido" para os padrões exigidos pelo idioma local.

Berman (1981) havia escolhido o texto de Arlt justamente por seu estilo imediatista, que, segundo ele, fez desse autor uma figura bastante polêmica, mas

10. E aqui explicitamos o termo utilizado no título desse ensaio, que apresenta o termo poética inspirado na leitura de Meschonnic, algo como uma "junção literária" de política e ética. 
também muito simbólica das letras argentinas. Em sua época, o autor argentino foi considerado pela crítica um escritor que praticava um realismo "de gosto execrável", e era acusado por "escrever mal"; em compensação, atualmente ele é visto pela nova geração como um escritor verdadeiramente moderno e o mais argentino de todos. Mas foi também esse estilo que apresentou um homem cuja vontade de ruptura estava acima de qualquer desejo de crítica elogiosa. Berman nos conta que Roberto Arlt chamava seu estilo de escrita de "prosa polifacética", e era aí que residia, segundo o autor francês, toda a originalidade do escritor argentino. Essa prosa, explica Berman, era "feita da coagulação, da brassagem, da mixagem, da fusão de várias 'linguagens' heterogêneas" (BERMAN, 1981, p.13). Entre essas linguagens heterogêneas encontravase o falar da Buenos Aires dos anos 1930, a gíria argentina, o lunfardo, o espanhol clássico e os léxicos típicos das traduções. De acordo com Berman, essas traduções traziam um espanhol antiquado e empolado, do qual se apresenta como exemplar a tradução de Crime e Castigo, de Dostoiévski, uma das maiores referências de Arlt. Mas não foi apenas essa fusão criativa de linguagens nessa escrita polifacética que levou Arlt a ser considerado o artista que inaugurou a nova fase da literatura argentina uma fase por sinal muito representativa da situação cultural desse país; para Berman (1981), essa época moderna da literatura argentina só surge a partir desse autor porque é ele que, ao pôr em prática essa fusão de linguagens, "rompe com toda uma tradição literária" (p.14).

Com a rejeição da crítica a sua tradução de Arlt - uma tradução que se espelhava na estética linguística criada por Arlt - foi que o ato de traduzir começou a se tornar uma questão e a ocupar todos os espaços nas reflexões Berman; como uma questão inseparável das questões éticas, sociais e políticas que envolvem a sua cultura. A tradução passa a ser o objeto que será usado por Berman para promover a reflexão e a prática da convivialidade em uma cultura etnocêntrica como a sua. A tradução em Berman pode ser vista, então, como objeto que denuncia um etnocentrismo cultural. Por isso, a atividade de tradução deixa de ser apenas uma fonte de renda para esse autor, tornando-se efetivamente o objeto de uma militância, como ele declara nas anotações que deixou para compor o que viria a ser seu projeto de babilitation: "minha obra (mesmo se querendo um trabalho histórico rigoroso) é um livro "militante". Ele milita por uma certa concepção da tradução, mas da literatura, da cultura e do ser-em-línguas humano" (BERMAN, 1991, nota 82).

Essa militância se inicia com o seu ensaio A tradução em manifesto (1984), publicado incialmente em tradução para o espanhol, na revista argentina Sitio (1981), depois como prefácio ao livro L'éprenve de l'étranger (1984). O título do ensaio tem leitura dupla, uma delas é a defesa da visibilidade da tradução, mas a outra, mais 
importante, por tudo o que falamos até agora, é a de servir como um manifesto, no sentido propriamente político de defesa de uma posição. Nele, Berman começa a propor um resgate da história da tradução francesa abortada para que assim seja possível pensar uma teoria realmente moderna para essa tarefa. Ele começa propondo um olhar crítico para a própria história a partir da história da tradução na Alemanha romântica, mas, para compor esse pensamento histórico, deixa preparada uma publicação póstuma, Jacques Amyot, traducteur français (2012), na qual propõe um resgate da história da tradução francesa de antes do classicismo, para desvelar dela o que havia de mais popular (e de convivial), e que, segundo ele, fora esquecido, para com isso conseguir, a partir da tradução, colocar a cultura e a linguagem própria em movimento crítico, autocrítico, transformador e, especialmente, em movimento de plena convivência com o estrangeiro.

Ao longo do seu curto tempo de vida, enquanto teórico da tradução, ele passa, portanto, benjaminiamente, a escovar a contrapelo a história da tradução francesa.

\section{REFERÊNCIAS BIBLIOGRÁFICAS E ELETRÔNICAS}

BEIRED, J.L.B. (1984). O movimento operário argentino: das origens ao peronismo (1890-1946). São Paulo: Brasiliense.

BERMAN, A. (1967). La tâche de la Poésie est simplement. Revue La Délirante, Paris, trimestral, jul., $n^{\circ} 1$, p.67-79

BERMAN, A. (1968). Lettres à Fouad El-Etr: sur le Romantisme allemand. Paris: La Délirante.

BERMAN, A. (1975). Maté et communication. Esprit (nouvelle série), nº 452. Paris: Seuil.

BERMAN, A.; GARMA, I. (1976). Trente ans de luttes nationales. Esprit (nouvelle série), $\mathrm{n}^{\mathrm{O}}$ 456. Paris: Seuil.

BERMAN, A.; GARMA, I. (1981). Avant-propos des traducteurs. In: ARLT, Roberto: Les sept fous. Traduit de l'espagnol (Argentine) par Isabelle et Antoine Berman. Paris: Belfond, p.13-19.

BERMAN, A. (1980). La voix des sans-voix - Arguedas, Garcia-Marquez, Scorza, RoaBastos. Canal - Dossier: Histoire \& Fiction dans la litterature d'Amerique Latine, $\mathrm{n}^{\mathrm{O}}$ 39. Paris : Communication, Arts et Cultures, p.4-5. 
BERMAN, A. (1984). La traduction au manifeste. In: L'épreuve de l'étranger: Culture et traduction dans l'Allemagne romantique. Paris: Gallimard, p.11-24.

BERMAN, A. (19[??]-1991). Document de synthèse [conjunto de notas numeradas]. Paris. (Manuscrito)

BERMAN, A. (2012). Jacques Amyot, traducteur français - Essai sur les origines de la traduction en France. Paris: Belin.

GRUPO SOLIDARITY (2003). Paris: maio de 68. São Paulo: Conrad, traduzido por Leo Vinícius. Disponível em: www.ebboksbrasil.org/adobeebook/maio68.pdf. Acesso em 18/02/2018.

LACOUE-LABARTHE, P.; NANCY, J.-L. (1978). L'absolu littéraire: Théorie de la littérature du Romantisme allemande. Paris: Seuil.

LES CAHIERS D’ARAN. (1969). Paris: Imprimerie Jean Munier, v. 1, n. 1. Trimestral.

PETRY, S.C. (2016). A tradução como obra: relações entre o conceito bermaniano de obra de arte e sua reflexão sobre tradução. Tese de doutorado. Curso de Teoria e História Literária, Instituto de Estudos da Linguagem, Unicamp, Campinas.

SELIGMANN-SILVA, M. (2011). A redescoberta do idealismo mágico. In: BENJAMIN, W.: O conceito de crítica de arte no romantismo alemão. $3^{\mathrm{a}}$ ed. São Paulo: Iluminuras, traduzido por Márcio Seligmann-Silva.

Recebido: 19/02/2018

Aceito: 03/03/2018 